\title{
Laboratory Shipment Record
}

National Cancer Institute

\section{Source}

National Cancer Institute. Laboratory Shipment Record. NCI Thesaurus. Code C115569.

Documentation detailing the shipment of a laboratory sample. 